\title{
Endodontic Management and Cone Beam Computed Tomography Assessment in a Four Rooted Maxillary First Molar
}

\author{
Vinoth kumar Deepa ${ }^{1, *}$, Kasinathan Subbaiah Satheesh Kumar \\ Department of Conservative dentistry and Endodontics, Rajah Muthiah Dental college and Hospital, Annamalai university, Tamil Nadu, \\ India \\ *Corresponding author: vindeepasri@gmail.com
}

Received September 20, 2014; Revised September 29, 2014; Accepted December 07, 2014

\begin{abstract}
The success of endodontic treatment not only lies in meticulous cleaning, perfect shaping and precise filling of canels, it also embodies vital importance on familiarity of unusual root canal patterns. This article presents a case report of a maxillary first molar that had two separate palatal roots with distinct canals and also an invitro assessment of an extracted tooth which had a a similar root canal morphology using cone beam computed tomography (CBCT). Both of them highlight the importance of knowing the anatomical variations to achieve a functional and biological favourable outcome in endodontic treatment.
\end{abstract}

Keywords: maxillary first molar, endodontic treatment, cone beam computed tomography (CBCT), root canal morphology

Cite This Article: Vinoth kumar Deepa, and Kasinathan Subbaiah Satheesh Kumar, "Endodontic Management and Cone Beam Computed Tomography Assessment in a Four Rooted Maxillary First Molar.” International Journal of Dental Sciences and Research, vol. 2, no. 6 (2014): 179-183. doi: 10.12691/ijdsr-2-6-15.

\section{Introduction}

The understanding of complex root canal system and the acquaintance of uncommon anatomical variations in teeth is vital and foremost for a successful root canal treatment. In spite of efficient chemo-mechanical preparation and proper obturation of root canal system, failure can result unless the clinician has a better cognition of the intricate root canal system and its frequent variations.

Majority of the maxillary first molars normally has three roots with independent canals. The mesiobuccal root is broad buccolingually and flatter mesiodistally. This root usually contains two canals and is associated with highest degree of anatomical variability. The frequency of MB2 canals in the mesiobuccal root was reported to be $92.85 \%$ (based on ex vivo results), 95.63\% (based on clinical results), and $95.45 \%$ (CBCT results) [1,2]. The distobuccal root is generally rounded or ovoid in cross section and usually contains a single canal. Variations of two or more canals do also exist $[1,3,4,5,6]$. The palatal root is more broad mesiodistally than buccolingually and ovoidal in shape but normally contains only a single canal. More rarely the palatal root exhibits anatomical diversification of root canal system with two or more canals $[4,5,6,7]$. Among the three roots, the least to show unusual morphology is the palatal root $[8,9,10]$. Extensive studies and case reports regarding the unusual anatomical variation and configuration of the root canal system in maxillary first molars have been illustrated. These include a single root canal in a single root $[11,12]$, two root canals [13], five root canals $[14,15,16,17,18]$, six root canals $[19,20,21]$, seven root canals [22], eight root canals [1], Cshaped canals [23,24], fusion of two buccal roots [25], fusion of two buccal roots with two palatal roots [26], four roots including an additional palatal root [27-33] and also five roots [31]. There are innumerable case reports and clinical studies of maxillary first molar on varied root canal morphology. Since this article is on extra palatal root, (Table 1) encapsulates all the case reports done so far in maxillary first molar with palatal root aberrations. Information pertaining to additional palatal root, total number of canals and root canal system classification are also summarized. A close inspection of this table reveals that the frequency of additional palatal root is quite less.

This article presents a case report of a maxillary first molar having two palatal roots with distinct canals and foramena at the apical level and also illustrates a detailed study of one such extracted tooth with cone-beam computed tomography.

\section{Case Report}

A 41 year old female patient complained of spontaneous pain in the decayed right maxillary first molar. On clinical examination, the tooth had a deep carious lesion on the distoocclusal surface. Pain on probing was present but the tooth was not tender to percussion. Periodontal probing was within physiological 
limits. Thermal and EPT vitality test was conducted and a response suggestive of irreversible pulpitis was elicited and endodontic treatment was planned. Assessment of preoperative radiograph revealed radiolucency of distal crown portion involving pulp chamber. Lamina dura remained intact. The information regarding number of roots and types of the root canals was inconclusive suggesting some type of morphological variations. Additional off-angle radiographs delineated an extra root.

Table 1. Summary of previous clinical cases with palatal root aberrations in maxillary first molar

\begin{tabular}{|c|c|c|c|c|c|c|}
\hline Author & Year & \multicolumn{2}{|c|}{ Type of study } & Number of & Number of & $\begin{array}{l}\text { Root canal system } \\
\text { classification }\end{array}$ \\
\hline Thews et al [27] & 1979 & a. & $\begin{array}{l}\text { Case report } \\
\text { Case report }\end{array}$ & $\begin{array}{l}2 \\
1 \\
\end{array}$ & $\begin{array}{l}1 \\
2 \\
\end{array}$ & $\begin{array}{c}\text { Type I } \\
\text { Type II } \\
\end{array}$ \\
\hline Harris [34] & 1980 & & Case report & 1 & 2 & Type IV \\
\hline Cecic et al [16] & 1982 & & Case report & 1 & 2 & Type V \\
\hline Bond et al [6] & 1988 & & Case report & 1 & 2 & Type II \\
\hline Wong [7] & 1991 & & Case report & 1 & 3 & $\begin{array}{l}\text { *Single canal with apical } \\
\text { trifurcation(1-3) Type IX }\end{array}$ \\
\hline Jacobsen and Nii [29] & 1994 & $\begin{array}{l}\text { a. } \\
\text { b. } \\
\text { c. }\end{array}$ & $\begin{array}{l}\text { Case report } \\
\text { Case report } \\
\text { Case report }\end{array}$ & $\begin{array}{l}1 \\
2 \\
1\end{array}$ & $\begin{array}{c}2 \\
1 \text { in each root } \\
2\end{array}$ & $\begin{array}{c}\text { Type II } \\
\text { Type I } \\
\text { Type V }\end{array}$ \\
\hline Holtzman [35] & 1997 & a. & $\begin{array}{l}\text { Case report } \\
\text { Case report }\end{array}$ & $\begin{array}{l}1 \\
1\end{array}$ & $\begin{array}{l}2 \\
2 \\
\end{array}$ & $\begin{array}{c}\text { Type II } \\
\text { Type IV }\end{array}$ \\
\hline Di fiore [28] & 1999 & & Case report & 2 & 1 in each root & Type I \\
\hline Filho et al [30] & 2002 & a. & $\begin{array}{c}\text { Case report } \\
\text { Ex vivo study }\end{array}$ & $\begin{array}{l}2 \\
2\end{array}$ & $\begin{array}{l}1 \text { in each root } \\
1 \text { in each root }\end{array}$ & $\begin{array}{l}\text { Type I } \\
\text { Type I }\end{array}$ \\
\hline Maggiore et al [36] & 2002 & & Case report & 1 & 3 & $\begin{array}{l}\text { *Single canal with apical } \\
\text { trifurcation(1-3) Type IX }\end{array}$ \\
\hline Barbizam et al [31] & 2004 & $\begin{array}{l}\text { a. } \\
\text { b. } \\
\text { c. }\end{array}$ & $\begin{array}{c}\text { Case report } \\
\text { Case report } \\
\text { Exvivo study } \\
\end{array}$ & $\begin{array}{l}2 \\
2 \\
2\end{array}$ & $\begin{array}{l}1 \text { in each root } \\
1 \text { in each root } \\
1 \text { in each root }\end{array}$ & $\begin{array}{l}\text { Type I } \\
\text { Type I } \\
\text { Type I } \\
\end{array}$ \\
\hline Adanir [5] & 2007 & & Case report & 2 & $\begin{array}{c}1 \text { canal in } \\
\text { one root } \\
2 \text { canals in } \\
\text { another root }\end{array}$ & $\begin{array}{l}\text { Type I } \\
\text { Type II }\end{array}$ \\
\hline Gopikrishna et al [26] & 2008 & & Case report & 2 & 1 in each root & Type I \\
\hline $\begin{array}{l}\text { Holderrieth and } \\
\text { Gernhardt [37] }\end{array}$ & 2009 & $\begin{array}{l}\text { a. } \\
\text { b. }\end{array}$ & $\begin{array}{l}\text { case report } \\
\text { case report }\end{array}$ & $\begin{array}{l}1 \\
1 \\
\end{array}$ & $\begin{array}{l}1 \\
2 \\
\end{array}$ & $\begin{array}{l}\text { Type V } \\
\text { Type IV }\end{array}$ \\
\hline Deepalakshmi etal [38] & 2010 & & case report & 1 & 2 & Type II \\
\hline Aggarwal et al [18] & 2009 & & case report & 1 & 2 & Type IV \\
\hline $\begin{array}{l}\text { Karthikeyan and } \\
\text { Mahalakshmi [21] }\end{array}$ & 2010 & $\begin{array}{l}\text { a. } \\
\text { b. } \\
\text { c. }\end{array}$ & $\begin{array}{l}\text { case report } \\
\text { case report } \\
\text { case report }\end{array}$ & $\begin{array}{l}1 \\
1 \\
1\end{array}$ & $\begin{array}{l}2 \\
2 \\
2\end{array}$ & Type II \\
\hline Johal [39] & 2001 & & case report & 1 & 2 & Type II \\
\hline Mirdha and Ponnapa [17] & 2011 & & case report & 1 & 2 & Type II \\
\hline Reddy et al [32] & 2011 & a. & $\begin{array}{l}\text { case report } \\
\text { case report }\end{array}$ & $\begin{array}{l}2 \\
1 \\
\end{array}$ & $\begin{array}{l}1 \text { in each root } \\
2 \\
\end{array}$ & $\begin{array}{l}\text { Type I } \\
\text { Type II }\end{array}$ \\
\hline Kottoor et al [1] & 2011 & & case report & 1 & 2 & Type II \\
\hline Yeganeh et al [40] & 2012 & & case report & 1 & 2 & Type IV \\
\hline Mathew et al [33] & 2013 & & case report & 2 & 1 in each root & Туре I \\
\hline
\end{tabular}

*Sert and Bayirli's Type IX

The tooth was isolated with a rubber dam under local anesthesia. Conventional coronal access was performed and pulp tissue removed. Four separate root canal orifices were found at the corners of a quadrangular shaped chamber floor. After scouting the canals with no. 10 and 15 Kfiles, coronal flaring with Gates glidden drill no.3 and no.2 was done. Working length was estimated with an apex locater (Propex Pixi, Dentsply Maillefer). A radiograph with the estimated working length was taken, this confirmed the real root length and the four independent roots, two buccal and two palatal classified as type I according to Christie et al [10].

The canals were instrumented initially with no.15 and no.20 K files followed by chemomechanical preparation with rotary Niti files (Protaper, Dentsply Maillefer,
Switerland) in a crown down technique. The working solution was 3\% sodium hypochlorite (Novo, dental products), changed with each file. 17\% EDTA (Desmear, Anabond Stedman, Pharma) solution was used to remove the smear layer. Final rinse was done with 2\% Chlorhexidine (RC-Chlor, Azure). The canals were dried with absorbent points and obturation was performed with gutta-percha and Zinc oxide eugenol sealer. Access cavity was sealed with composite material (ValuX plus, 3M ESPE) and an appropriate definitive coronal restoration was planned. After a 12 month period, the patient was reviewed and was found clinically asymptomatic. An orthopantogram (OPG) was taken as an evaluative radiograph. (Figure $1 \mathrm{~A}-\mathrm{C}$ ). 

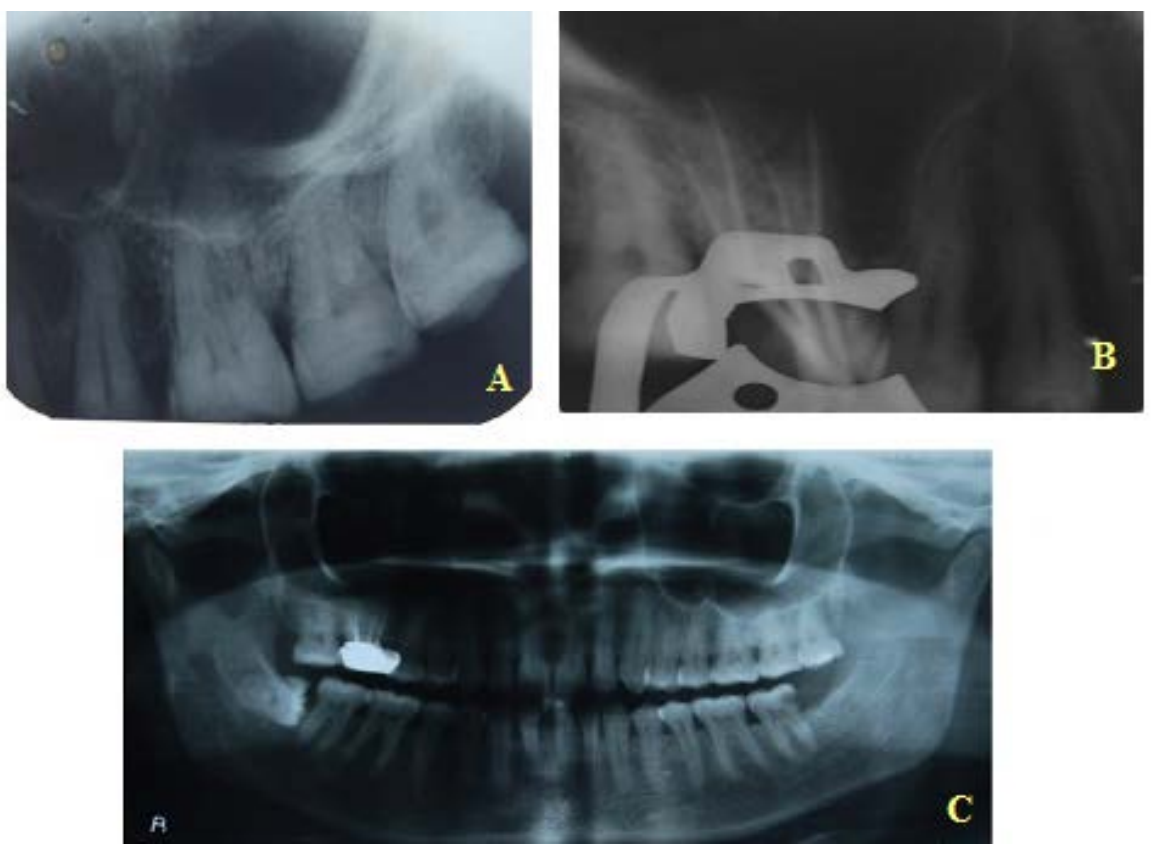

Figure 1. Right maxillary first molar with four roots. (A) Preoperative radiograph. (B) Master cone radiograph. (C) OPG after one year follow-up to simultaneously check for bilateral presence

\section{Cone Beam Computer Tomography (CBCT)}

CBCT imaging was performed on an extracted maxillary molar with 4 roots to study the internal root canal anatomy. This tooth had been extracted from a patient in surgery department due to poor periodontal prognosis. 3D imaging was done with a CBCT scanner (Planmeca Promax 3D Mid, Chennai, India ) at a tube voltage of $90 \mathrm{kvp}$ and tube current of $10 \mathrm{~mA}$. Axial slices of molar tooth of $200 \mu \mathrm{m}$ thickness were obtained at different levels to exactly evaluate the root canal pattern in the 4 roots. The axial images were transmitted to a commercially available dental program (Planmeca Romexis Software) to reformat into 3-dimensional images in all three planes.

CT scan slices revealed 4 roots and 4 root canals. All the 4 roots- mesiobuccal, distobuccal , mesiopalatal and distopalatal roots presented with a Vertucci type I and Weine type I canal pattern (Figure 2 A-E). The anatomic laws generally act as a guidance for proper access and exact location of canal orifices [41]. All anatomic laws are applicable to maxillary molars except Laws of symmetry 1 and 2 . The Law of symmetry 1 states that the orifices of the canals are equidistant from a line drawn in a mesialdistal direction through the center of the pulp chamber floor. Law of symmetry 2 states that the orifices of the canals lie on a line perpendicular to a line drawn in a mesial-distal direction through the center of the pulp chamber floor. On examining the pulp chamber floor of a maxillary molar with 4 roots having a Christie et al type I root pattern, both the Laws of symmetry 1 and 2 are appropriate and applicable (Figure $2 \mathrm{~B}$ ).

CBCT reconstructed images are invaluable for assessing the variations in root canal anatomy In fact the datas obtained can be considered as "Gold standard". If radiographs are considered to be the "eyes" of the dentist according to Walton, then CBCT can be considered as a "true vision" to endodontist.
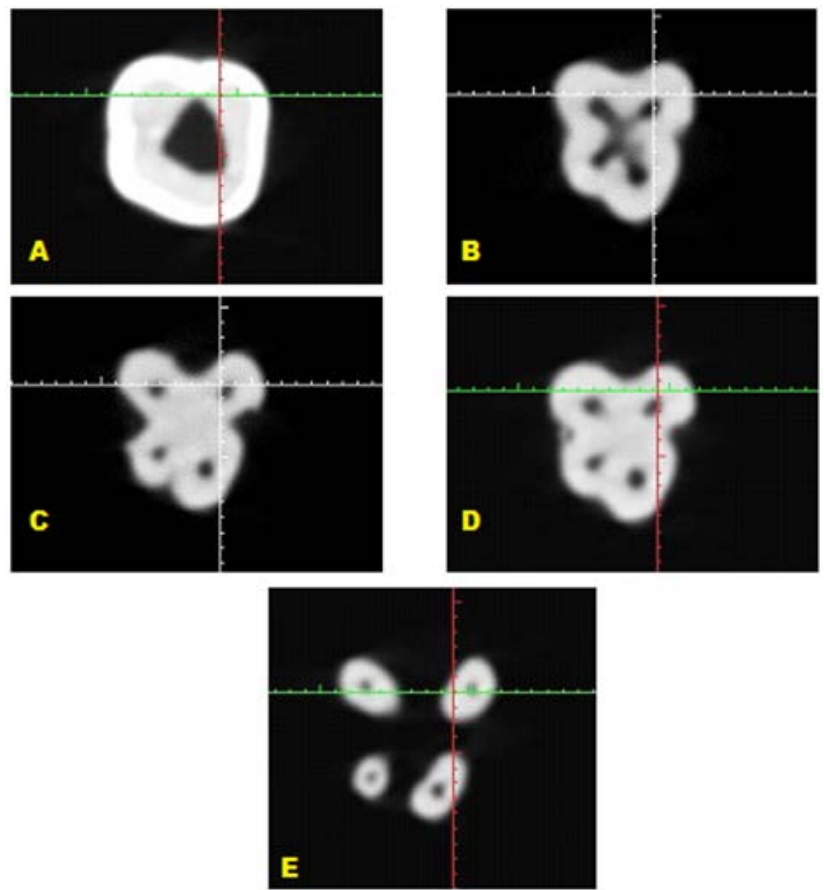

Figure 2. CBCT images of an extracted maxillary molar with four roots showing axial sections. (A) Root of pulp chamber; (B) Floor of pulp chamber; (C) Tetrafurcation level (D) Middle $1 / 3^{\text {rd }}$; (E) Apical $1 / 3^{\text {rd }}$

\section{Discussion}

Extensive literature [9,45], clinical study $[2,8,30,41,46,47,48,49]$ and case reports are presented on maxillary first molars (Table 2). Among the root canal anomalies of maxillary molars, the least frequent appears to be that of palatal root. In reviewing root and canal morphology according to Cleghorn et al [9] the frequency of a maxillary first molar with two roots or two palatal canals is very low 3.9 and $1 \%$ respectively. The presence of double palatal roots in maxillary molar is quite a rare phenomenon most frequently limited to maxillary second 
molar. Many reports and clinical studies of second maxillary molar with 4 roots are published. Libfeld and Rostein [45] in a survey of 1200 maxillary second molars found $0.4 \%$ of the sample having this condition. Peikoff et al [50] indicated the frequency of variation to be around $1.4 \%$.

Table 2. List of reviews and anatomical studies on maxillary first and second molars

\begin{tabular}{|l|r|l|}
\hline \multicolumn{1}{|c|}{ Author } & Year & \multicolumn{1}{c|}{ Type of study } \\
\hline Libfeld and Rotstein [45] & 1989 & Review and radiographic assessment \\
\hline Christie et al [10] & 1991 & Retrospective study \\
\hline Pecora et al [46] & 1992 & Clinical study \\
\hline Sempira and Hartwell [47] & 2000 & Clinical study \\
\hline Krasner and Rankow [41] & 2004 & Clinical study \\
\hline Cleghorn et al [9] & 2006 & Review \\
\hline Filho et al [2] & 2009 & Clinical study \\
\hline Neelakantan et al [44] & 2010 & Micro-computed tomography study \\
\hline Versiani et al [48] & 2012 & CBCT study \\
\hline
\end{tabular}

Christie et al [10] also speculated that maxillary molars with 2 palatal roots may be encountered once every 3 years in a busy endodontic practice. The frequency of 4 rooted anatomy in maxillary $1^{\text {st }}$ molars is extremely low. Very few case reports of maxillary $1^{\text {st }}$ molar with 4 roots are discussed (Table 1).

The dentist should posses thorough knowledge and be aware that any tooth in the dental arch can present with unusual anatomical variations. To treat such cases successfully a schematic representation in access management "Access Success Triad" which includes triple 'A'- Armamentarium, Acquaintance to extra canals and Advanced diagnostic aids is shown in (Figure 3).The ultimate goal of endodontic treatment is to create a conducive environment for effective healing. To achieve this proper access is of prime importance. Successful access management followed by procedure such as cleaning, shaping, filling and final restoration leads to eventual endodontic success.

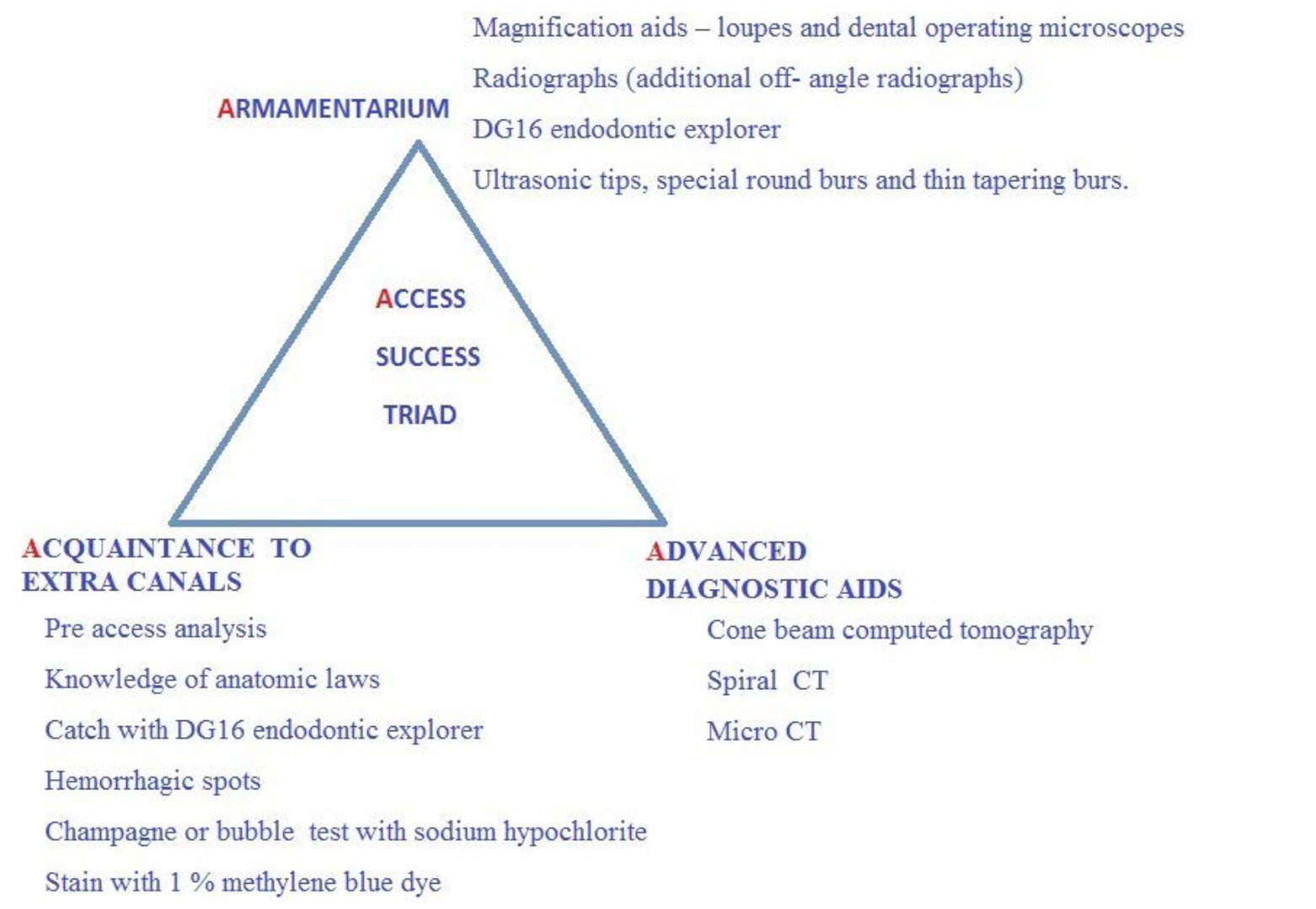

Figure 3. A schematic representation of a successful access management in teeth with uncommon morphological variztion

\section{Conclusion}

A careful exploration of radiographs and if required additional advanced diagnostic tools like CBCT, Micro CT are essential. Awareness regarding possible variations in internal anatomy of teeth is of paramount significance in treating the challenges of pulp space anatomy and eventually leading to success in root canal treatment.

\section{Conflict of Interests}

The authors declare that there is no conflict of interests regarding the publication of this paper.

\section{References}

[1] Kottoor J, Velmurugan N and Surendran S. Endodontic management of a maxillary first molar with eight root canal systems evaluated using cone - beam computed tomography scanning: A case report. J Endod. 2011; 37 (5):715-719.

[2] Baratto-Filho F, Zaitter S , Haragushiku GA , De Campos EA, Abuabara A et al. Analysis Of The Internal Anatomy Of Maxillary First Molars By Using Different Methods. J Endod. 2009; 35 (3): 337-342.

[3] Hulsmann M. A Maxillary First Molar with Two Disto-buccal Root Canals. J Endod. 1997; 23 (11): 707-708.

[4] Karthikeyan K and Mahalakshmi S. New Nomenclature For Extra Canals Based On Four Reported Cases Of Maxillary First Molars With Six Canals:A Case Report. J Endod. 2010; 36(6): 1073-1077.

[5] Adanir N. An unusual maxillary first molar with four roots and six canals: a case report. Aust Dent J. 2007; 52(4): 333-335. 
[6] Bond JL, Hartwell G and Portell FR. Maxillary First Molar with Six Canals. J Endod. 1988; 14 (5): 258-260.

[7] Wong M. Maxillary First Molar with Three Palatal Canals. J Endod. 1991; 17(6): 298-299.

[8] Stropko JJ. Canal Morphology of Maxillary Molars: Clinical Observations of Canal Configurations. J Endod. 1999; 25 (6): 446450.

[9] Cleghorn BM, Christie WH, Cecilia C and Dong S. Root and Root Canal Morphology of the Human Permanent Maxillary First Molar: A Literature Review. J Endod. 2006; 32 (9): 813-820.

[10] Christie WH, Peikoff and Fogel FH. Maxillary Molars with Two Palatal Roots: A Retrospective Clinical Study. J Endod. 1991; 17(2): 80-84.

[11] Gopikrishna V, Bhargavi N and Kandaswamy D. Endodontic management of a maxillary first molar with a single root and a single canal diagnosed with the aid of spiral CT: a case report. J Endod. 2006; 32(7): 687-691.

[12] Cobankara FK, Terlemez A and Orucoglu H. Maxillary first molar with an unusual morphology: report of a rare case. Oral Surg Oral Med Oral Pathol Oral Radiol Endod. 2008; 106(6): 62-65.

[13] Ma L, Chen J and Wang $\mathrm{H}$. Root canal treatment in an unusual maxillary first molar diagnosed with the aid of spiral computerized tomography and in vitro sectioning: a case report. Oral Surg Oral Med Oral Pathol Oral Radiol Endod. 2009; 107 (6): 68-73.

[14] Beatty RG. A Five-canal Maxillary First Molar. J Endod. 1984; 10(4): 156-157.

[15] Martins JNR and Anderson C. Endodontic treatment of the maxillary first molar with five root canals - Three case reports.Rev Port Estomatol Med Dent Cir Maxilofac. 2013; 54(1): 37-42.

[16] Cecic P, Hartwell G and Bellizzi R. The Multiple Root Canal System in the Maxillary First Molar: A Case Report. J Endod. 1982; 8(3): 113-115.

[17] Mirdha N and Ponnapa KC. Endodontic Management of Maxillary First Molar with 2 Palatal And 3 Buccal Canals And Associated With Multiple Space Infections. International Oral Health Journal. 2011; 3(3): 31-36.

[18] Aggarwal V, Singla M, Logani A and Shah N. Endodontic management of a maxillary first molar with two palatal canals with the aid of spiral computed tomography: a case report. J Endod. 2009; 35(1): 137-139.

[19] Albuquerque DV, Kottoor J, Dham S, Velmurugan $\mathrm{N}$, Abarajithan $\mathrm{M}$ and Sudha R. Endodontic management of maxillary permanent first molar with 6 root canals: 3 case reports. Oral Surg Oral Med Oral Pathol Oral Radiol Endod. 2010; 110(4): 79-83.

[20] Martinez-Berna A and Ruiz-Badanelli P. Maxillary first molars with six canals. J Endod. 1983; 9(9): 375-381.

[21] Karthikeyan K and Mahalakshmi S. New Nomenclature For Extra Canals Based On Four Reported Cases Of Maxillary First Molars With Six Canals: A Case Report.J Endod. 2010; 36(6): 1073-1078.

[22] Kottoor J ,Velmurugan N, Sudha R and Hemamalathi S. Maxillary first molar with seven root canals diagnosed with cone-beam computed tomography scanning: a case report. J Endod. 2010; 36(5): 915-921.

[23] Dankner E, Friedman S and Stabholz A. Bilateral C shape configuration in maxillary first molars. J Endod. 1990; 16(12): 601-603.

[24] Yilmaz Z, Tuncel B, Serper A and Calt S. C-Shaped root canal in a maxillary first molar: a case report. Int Endod J. 2006; 39(2): 162-166.

[25] Malagnino V, Gallottini L and Passariello P. Some unusual clinical cases on root anatomy of permanent maxillary molars. J Endod. 1997; 23(2): 127-128.

[26] Gopikrishna V, Reuben J and Kandaswamy D. Endodontic management of a maxillary first molar with two palatal roots and a single fused buccal root diagnosed with spiral computed tomography — a case report. Oral Surg Oral Med Oral Pathol Oral Radiol Endod. 2008; 105(4): 74-78.

[27] Thews ME , Kemp WB and Jones Richmond CR. Aberrations in Palatal Root and Root Canal Morphology of Two Maxillary First Molars. J Endod. 1979; 5(3): 94- 96.
[28] Di Fiore Peter M. A Four-Rooted Quadrangular Maxillary Molar. J Endod. 1999; 2 (10): 695-697.

[29] Jacobsen EL and Nii C. Unusual palatal root canal morphology in maxillary molars. Endod Dent Traumatol. 1994; 10(1): 19-22.

[30] Baratto-Filho F, Fariniuk LF, Ferreira EL, Pecora JD, Cruz-Filho AM and Sousa-Neto MD. Clinical and Macroscopic Study Of Maxillary Molars With Two Palatal Roots. Int Endod J. 2002; 35(9): 796-801.

[31] Baroni Barbizam JV, Ribeiro RG and Filho MT. Unusual Anatomy of Permanent Maxillary Molars. J Endod. 2004; 30(9): 668-671.

[32] Reddy SJ, Ravichandra PV, Rajani P and Santhoshi L. Palatal Possibilities:Variations of Palatal Root Canal Configuration In Maxillary Molars-A Report Of Two Cases. Int. Journal of Contemporary Dentistry. 2011; 2(2): 85-90.

[33] Mathew J, Devadathan A, Jacob J, Syriac G and Augustine JC. Root canal treatment of a maxillary first molar with an unusual presentation of two palatal roots. Health Sciences. 2013; 2(3): 1-8.

[34] Harris WE. Unusual Root Canal Anatomy in A Maxillary Molar. J Endod. 1980; 6 (5): 573-575.

[35] Holtzman L. Multiple Canal Morphology In The Maxillary First Molar:Case Reports. Quintessence Int. 1997; 28(7): 453-455.

[36] Maggiore F, Jou YT and Kim S. A six-canal maxillary first molar: case report. Int Endod J. 2002; 35(5): 486-491.

[37] Holderrieth S and Gernhardt CR. Maxillary Molars with Morphologic Variations Of The Palatal Root Canals: A Report of Four Cases. J Endod. 2009; 35(7): 1061-1065.

[38] Deepalakshmi M, Miglani R, Indira R and Ramachandran S. Spiral CT diagnosis and endodontic management of an anatomically variant palatal root with two canals in a maxillary first molar. Indian J Dent Res.2010; 21(3): 443-445.

[39] Johal S. Unusual maxillary first molar with 2 palatal canals within a single root: a case report. J Can Dent Assoc.2001; 67(4): 211214.

[40] Yeganeh LA, Adel M, Vahedi R and Tofangchiha M. Endodontic Management Of A Maxillary First Molar With Two Palatal Canals And A Single Buccal Canal: A Case Report. Case Reports in Dentistry. 2012: 1-4.

[41] Krasner P and Henry JK. Anatomy of the Pulp Chamber Floor. J Endod. 2004; 30(1): 5-15.

[42] Patel S. New dimensions in endodontic imaging: part2. Cone beam computed tomography. Int Endod J. 2009; 42(6): 463-475.

[43] Michetti J, Maret D, Mallet JP and Diemer F. Validation of cone beam computed tomography as a tool to explore root canal anatomy. J Endod. 2010; 36(7): 1187-1190.

[44] Neelakantan P, Subbarao C, Ahuja R, Subbarao CV and Gutmann JL. Cone beam computed tomography study of root and canal morphology of maxillary first and second molars in an Indian population. J Endod. 2010; 36(10): 1622-1627.

[45] Libfeld $\mathrm{H}$ and Rotstein I. Incidence of Four-rooted Maxillary Second Molars: Literature Review and Radiographic Survey of 1,200 Teeth. J Endod. 1989; 15(3): 129-131.

[46] Pecora JD, Woelfel JB, Sousa Neto MD and Pacheco E. Morphologic Study of Maxillary Molars part II: Internal Anatomy. Braz Dent J. 1992; 3(1): 53-57.

[47] Sempira HN and Hartwell GR. Frequency of Second Mesiobuccal Canals in Maxillary Molars as Determined by Use of an Operating Microscope: A Clinical Study. J Endod. 2000; 26(11): 673-674.

[48] Versiani MA, Pecora MD and De Sousa-Neto. Root and Root canal Morphology of Four- rooted Maxillary second Molars: A Micro- Computed Tomography Study. J Endod.2012; 38(7): 977982.

[49] Corcoran J, Apicella MJ and Mines P. The Effect of Operator Experience in Locating Additional Canals In Maxillary First Molars. J Endod. 2007; 33(1): 15-17.

[50] Peikoff MD, Christie WH and Fogel HM. The maxillary second molar: Variations in the number of roots and canals. Int Endod J. 1996; 29(6): 365-369. 